\title{
Five new records, new localities and new host plants for the Turkish flea-beetle fauna (Coleoptera: Chrysomelidae: Alticinae)
}

\author{
Irfan Aslan, Hikmet Özbek \& Andrzej Warchalowski
}

\begin{abstract}
Aslan, I., Özbek, H. \& Warchalowski, A. 2004: Five new records, new localities and new host plants for the Turkish flea-beetle fauna (Coleoptera: Chrysomelidae: Alticinae). — Entomol. Fennica 15: 138-141.

Altica lencorana Konstantinov, A. longicollis (Allard), Aphthona atrocaerulae (Stephens), A. violaceae (Koch), and Phyllotreta lorestanica Warchalowski are new for the Turkish Alticinae fauna. A. lencorana and $P$. lorestanica have earlier been known to occur only in their type localities in Azerbaijan and Iran, respectively. Since then, the records reported here (Bayburt and Erzurum provinces) are the first localities for A. lencorana, and that of Erzurum for $P$. lorestanica. Additionally, Centaurea glastifolia L. is reported as a new host plant for A. lencorana, and Euphorbia falcate and E. eriophora as new host plants of Aphthona atrocaerulea and $A$. violaceae, respectively. The chorotype and host plants are reported for each of the five species.
\end{abstract}

I. Aslan \& H. Özbek, Atatürk University, Agricultural Faculty, Plant Production Department,25240Erzurum,Turkey;E-mail: iaslan@atauni.edu.tr,aslanir@, hotmail.com

A. Warchalowski, Zoological Instute, University of Wroclaw, Sienkiewicza 21, 50-335 Wroclaw, Poland.

Received 21 January 2004, accepted 3 July 2004

\section{Introduction}

The leaf beetles (Chrysomelidae) are the secondlargest family of Coleoptera, comprising approximately 50,000 described species worldwide, arranged in over 2,000 genera in 19 subfamilies (Lopatin 1977, Seeno \& Wilcox 1982, Booth et al. 1990, Konstantinov \& Vandenberg 1996). The flea beetles (Alticinae) constitute the largest of the 15 or more subfamilies recognized by most authors (Jolivet et al. 1988, Gruev \& Döberl 1997).

Several studies have recently been conducted on the leaf-beetle fauna of Turkey (Aslan 1997, Gruev \& Aslan 1998, Aslan \& Özbek 1998,
1999, 2000a, 2000b, Aslan \& Warchalowski 2001, Aslan et al. 1999, 2002, 2003, Fritzlar 2001, Gök et al. 2002). In these contributions, various species have been described and new records have been added to the Turkish fauna.

The present study is based upon the flea-beetle samples collected from different parts of the country during 1998-2003. In the collection of the insect samples, hand sweep net and mouth aspirator have been used. To identify the host plants, plants damaged by insects were examined and chrysomelids on these plants were collected. The identification of the flea-beetle genera Altica, Aphthona and Phyllotreta was based on the keys by Lopatin (1977), Konstantinov (1988) and 
Warchalowski (2003). In the chorotype classification, Vigna Talgianti et al (1999) was followed.

The examined material is deposited at the Atatürk University, Entomology Museum Erzurum, Turkey (EMET).

\section{Results}

Altica lencorana Konstantinov, 1991

Altica lencorana Konstantinov, Insect of the Caucasus, Makhachkala 1: 41-42.

Material examined. Erzurum, Horasan, Sac Pass, $2350 \mathrm{~m}$ a.s.l., 27.VIII.2003, $15 \hat{\delta} \hat{\delta}, 17$ qq; leg. İ. Aslan; Bayburt, Kop Mountain, $2330 \mathrm{~m}$ a.s.l., 28. VIII.2003, $17 \hat{\jmath} \hat{\jmath}, 13$ qq, leg. İ. Aslan.

Host plants. In both localities, the samples were collected on Centaurea glastifolia L.

Distribution. Azerbaijan (Gruev \& Döberl 1997, Warchalowski 2003).

Remarks. Konstantinov (1995) redescribed this species as a new species. The descriptions of A. lencorana and A. talyshana are almost identical. Konstantinov (1995) did not propose $A$. talyshana to be a new name for $A$. lencorana. Gruev \& Döberl (1997) considered A. talyshana as a synonymy of $A$. lencorana.

In this species, the apical part of the median stripe was deeply impressed, narrower than $1 / 3$ of aedeagus in apical part.

\section{Altica longicollis (Allard, 1860)}

Graptodera longicollis Allard, Ann. Soc. Ent. Fr., 3: 76-83.

Material examined. Ankara, Şereflikoçhisar, 21.VII.1998, 2 đ̊, 1 q; leg. C. Guclu; Aksaray, Ortaköy, 28.VII.2000, 1 ô, 1 q, leg. İ. Aslan.

Host plants. The insect samples collected in Ortaköy (Aksaray) were found on Rumex spp.

Distribution. Northern and Central Europe from Northern Spain, England and Norway to Germany, Poland and Karelia (Warchalowski 2003).

Remarks. According to Gruev \& Döberl (1997), erroneous records of this species have been published in Turkey and Italy.

In this species, the median stripe in $1 / 3$ length of tubular part is distinctly narrowed. Upper side is greenish blue. Frontal calli are approximately triangular, distinctly separated from frons by deep frontal furrows.

Aphthona atrocaerulea (Stephens, 1831)

Haltica atrocaerulea Stephens, Illustr. Brit. Ent. 4: 299-300.

Material examined. Erzurum, Aşkale, $1650 \mathrm{~m}$ a.s.1., 1.VI.1999, 1 §, 2 qq; Tortum, Karl1, 2400 m, 22.IX.2002, $7 \hat{\jmath} \hat{\jmath}, 5$ q + , leg. İ. Aslan.

Host plants. All of the specimens were collected from Euphorbia falcata L.. Konstantinov (1998) indicated Euphorbia cyparissias, E. esula and $E$. segetalis as host plants for this species.

Distribution. Europe, Northern Africa and Iran (Konstantinov 1998, Warchalowski 2003).

Remarks. According to Gruev \& Döberl (1997), erroneous records of this species have been reported in Greece, Caucasus and Iran. Distributed as reported above, but in Turkey may possibly represent the insufficiently described Aphthona kocheri Kral, 1969 from Morocco.

Aphthona violacea (Koch, 1803)

Haltica violacea Koch, Ent. Hefte 2: 56.

Material examined. Yalova, Bahce Kültürleri Arastırma Enstitüsü, $5 \mathrm{~m}$ a.s.1., 27.IV.2003, 3 $\hat{\jmath} \hat{\jmath}, 4$ qq, leg. H. Özbek.

Host plants. All of the specimens were collected from Euphorbia eriophora Boiss. Euphorbia palustris was reported as being a host plant by Bedel (1889-1901), and E. esula and E. lucida by Konstantinov (1998).

Distribution. Europe, Caucasian countries, Altai and Southern Siberia (Konstantinov 1998, Warchalowski 2003).

Phyllotreta lorestanica Warchalowski, 1973

Phyllotreta atra lorestanica Warchalowski, Pol. Pis. Ent. 43: 664-665.

Material examined. Erzurum, Hınıs, $1550 \mathrm{~m}$ a.s.l., 14.VI.2002, $2 \hat{\delta} \hat{\sigma}, 4 q q$, leg. İ. Aslan.

Host plants. All of the specimens were collected from Lepidium spp.

Distribution. Northern Iran (Gruev \& Döberl 1997, Warchalowski 1994). 


\section{Discussion}

Many Alticinae species are serious pests that cause direct damages on their host plants, and especially adults are also known to transmit viruses (Lopatin 1977, Jolivet et al. 1988, Konstantinov 1998, Aslan et al. 1999). Several species, including Longitarsus, Altica, Aphthona and Pseudolampsis, have been successfully used in the biological control of weeds (Booth et al. 1990, Aslan \& Özbek 1999, Aslan et al. 2003). The species of Alticinae that occur in Turkey can be divided mainly into two groups from the agricultural point of view, namely as being "destructive" (pest) and "useful" insects. Phyllotreta atra, P. nigripes, $P$. undulata and $P$. vittula, are important pests on cabbage, radish, turnip and rape in Turkey (Aslan \& Özbek 2000b). Chaetocnema tibialis, C. concinna, C. hortensis and C. breviuscula are important pests on sugar beet in Turkey (Aslan \& Özbek 1998). The second group can be considered as useful insects due to their feeding on various species of weeds. They are mostly leaf feeders. Recently, the use of herbicides in control is often not considered practical or desirable. Therefore, for some groups of weeds, biological control has become a widelyused strategy for control of pest weeds. Among these species, Longitarsus jacobaea is one of the most effective biological control agents of Senecio jacobaeae (Aslan \& Özbek 1999). Aphthona flava and A. nigriscutis are important biological control agents of the leafy spurge. Psylliodes chalcomera and $P$. hyosciyami have special importance in the biological control of Carduus nutans and Hyoscymus niger, respectively (Aslan \& Özbek 1999).

So far Altica lencorana has been known to occur only in the type locality in Azerbaijan. However, we recorded it from Bayburt and Erzurum provinces in Turkey. Since the records from the type locality, Bayburt and Erzurum are the first ones for this species, and its westernmost areas of distribution reach these two provinces. The present data suggests that it is associated with the Turanian Anatolian chorotype. More importantly, Centaurea glastifolia was determined as its host plant for the first time. We observed that the adults and larvae of $A$. lencorana seriously damaged leaves of $C$. glastifolia. However, re- search should be conducted to investigate the potential of $A$. lencorana for the control of C. glastifolia. This plant is an important weed in pastures and meadows, particularly in eastern and central Turkey.

Although Gruev \& Döberl (1997) suggested that the occurrence of Altica longicollis is questionable in Turkey and even in Italy, we recorded A. longicollis for the first time for Turkey and the Asian continent. The south-eastern distribution of this species has extended to central Turkey. With present data, its chorological category could be Siberio-European chorotype.

Although Aphthona atrocaerulea has wide geographical distribution (Konstantinov 1998, Warchalowski 2003), it was recorded from Turkey for the first time. Gruev \& Döberl (1997) pointed out that the existence of this species is questionable in Greece, Caucasus and Iran. However, our studies showed that this species occurs in Turkey. We assume that $A$. atrocaerulea may also inhabit the other mentioned countries. Another important point is that Euphorbia falcate was recorded as a new host plant for $A$. atrocaerulea. As the previous species, also Aphthona violaceae has wide geographical distribution, although we reported it as a new species for the Turkish fauna. Euphorbia eriophora is a new host plant for $A$. violaceae.

Warchalowski described Phyllotreta lorestanica in 1973 from Iran (Konstantinov 1998, Warchalowski 2003). After the type locality, Erzurum (Turkey) is the first locality for this species and Lepidium sp. is the first-recorded host plant of this species. With present data P. lorestanica has Irano-Anatolian chorotype.

We conclude that the Chrysomelidae fauna of Turkey should be studied more intensively.

\section{References}

Aslan, I. 1997: Faunistic and Systematic studies on the subfamily Alticinae (Coleoptera, Chrysomelidae) in Erzurum provinces of Turkey. - PhD thesis, Erzurum, Atatürk University. 215 pp. [in Turkish with English summary]

Aslan, I. \& Ozbek, H. 1998: Leaf-Beetles (Chrysomelidae) as Vegetable Pest in Erzurum. - Proceedings of The Second Vegetable Symposium, 28-30 September 1998, Tokat: 335-340. [in Turkish with English summary] 
Aslan, I. \& Ozbek, H. 1999: Occurence of leaf-beetles (Coleoptera, Chrysomelidae) in the vicinity of Erzurum cause significant damage on weeds. Proceedinds of the Forth Turkish National Congress of Entomology, 26-29 January 1999, Adana: 75-86. [in Turkish with English summary]

Aslan, I. \& Ozbek, H. 2000a: New Records of leaf beetles, Chrysomelidae (Coleoptera) from Turkey. — J. Ent. Res. Soc. 2 (1): 1-7.

Aslan, I. \& Ozbek, H. 2000b: Phyllotreta (Coleoptera, Chersomelidae, Alticinae) species, their biology and damage in some vegetables in Cruciferae family. Proceedings of The Third Vegetable Symposium, 1113 September 2000, Isparta: 203-207. [in Turkish with English summary]

Aslan, I. \& Warchalowski, A. 2001: New records of the subfamily Alticinae (Coleoptera, Chrysomelidae) for the Turkish fauna. - J. Ent. Res. Soc. 3 (1-2): 1-4.

Aslan, I., Gruev, B. \& Ozbek, H. 1999: A Preliminary Review of the Subfamily Alticinae (Coleoptera, Chrysomelidae) in Turkey. - Tr. J. Zool. 3 (4): 373-414.

Aslan, I., Been, R. \& Ozbek, H. 2002: New records of leaf beetles from Turkey (Coleoptera, Chrysomelidae). Ent. B1. 98: 231-235.

Aslan I., Ozbek, H. \& Konstantinov, A. 2003: Flea beetles (Coleoptera, Chrysomelidae) occuring on Amaranthus retreflexus L. in Erzurum province, Turkey, and their potential as biological control agents. - Proc. Entomol. Soc. Wash. 105 (2): 441-446.

Bedel, L. 1889-1901: Faune des Coleopteres du Bassin de la Seine. - Societe entomologique de France 5: 166 205.

Booth, R.G., Cox, M. L. \& Madge, R.B. 1990: IIE Guides to Insects of Importance to Man. 3. Coleoptera. - International Institute of Entomology, The Natural History Museum. 384 pp.

Fritzlar, F. 2001: Aphthona warchalowski n. sp., Aphthona bergeali n. sp., Longitarsus angelikae n. sp. und Longitarsus meridionalis Weise, 1888 n. stat. 4 Blattkäfer (Coleoptera, Chrysomelidae, Alticinae) aus der südwestlichen Türkei. — Ent. B1. 97: 199-224.

Gök, A., Cilbiroglu, E. B., Ayvaz, Y. \& Yildirim, M. Z.
2002: Two new records for the Turkish flea beetles fauna: Phyllotreta reitteri Heik., 1911 and Epitrix diecmanni Mohr, 1968 (Coleoptera, Chrysomelidae, Alticinae). - Isr. J. Zool. 48: 254-255.

Gruev, B. \& Döberl, M. 1997: General distribution of the flea beetles in the palearctic subregion. - Museum Historiae Naturalis Slovenia. Ljubljana Scopolia 37. 496 pp.

Gruev, B. \& Aslan, I. 1998: Four new species of the subfamily Alticinae (Coleoptera, Chrysomelidae) from Turkey. - Türk Entomol. Derg. 22 (3): 163-169.

Jolivet, P., Petitpierre, E. \& Hasiao, T.H. 1998: Biology of Chrysomelidae. - Series Entomologicia, Volume 42, Kluver Academic Publishers. 606 pp.

Konstantinov, A. S. 1998: Revision of the Palearctic species of Aphthona Chevrolat and cladistic classification of the Aphthonini (Coleptera: Chrysomelidae: Alticinae). - Memoirs on Entomology, International Vol. 111, Associated Publishers, Gainesville, Florida. 429 pp.

Konstantinov, A.S. \& Vandenberg, N.J. 1996: Handbook of Palearctic Flea Beetles (Coleoptera: Chrysomelidae: Alticinae). Vol. 1, Number 3. - Associated Publishers, Gainesville, Florida. 439 pp.

Lopatin, I. K. 1977: Leaf-Beetles (Chrysomelidae) of Middle Asia and Kazakhstan. - Nauka. 289 pp.

Seeno, T. N. \& Wilcox, J. A. 1982: Leaf Beetle Genera (Coleoptera: Chrysomelidae). - Entomography Sacramento, California 1: 1-222.

Vigna Taglianti, A., Audisio, P. A., Biondi, M., Bologna, M. A., Cappaneto, G. M., De Biase, A., Fattorini, S., Piatella, E., Sindaco, R., Venchi, A. \& Zaporoli, M. 1999: A proposal for a chorotyupe classification of the Near East fauna, in the framework of the Westren Palearctic region. - Biogeographia XX, 1: 31-59.

Warchalowski, A. 1994: Über den taxonomischen Rang von Phyllotreta lorestanica Warchalowski. - Genus 5: $173-175$.

Warchalowski, A. 2003: Chrysomelidae, The Leaf-Beetles of Europe and the Mediterranean Area. - Natura Optima Dux Foundation Warszawa. 600 pp. 